\title{
Ameliorative effect of Psidium guajava (I.) leaf aqueous extract on aluminium nitrate- induced liver damage in female Wistar rats
}

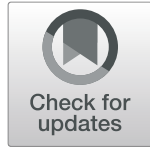

\author{
Aanuoluwapo Adeyimika Afolabi ${ }^{1^{*}}$, Ebenezer Adeola Ashamu and Olufemi Idowu Oluranti ${ }^{2}$
}

\begin{abstract}
Background: Aluminium nitrate and other aluminium-containing compounds have been demonstrated to cause several health challenges. Psidium guajava $\mathrm{L}$ ) is a well known cultivated tree with hepatoprotective nature and radical scavenging ability.

Methods: Twenty-five (25) female Wistar rats with average weight of $195 \mathrm{~g}$ were grouped into five groups $(n=5)$, with their weights measured and recorded weekly throughout the period of 21 days of the research. Control (group A), $32.5 \mathrm{mg} / \mathrm{kg}$ AL only (group B), $30 \mathrm{mg} / \mathrm{kg} \mathrm{AL}+250 \mathrm{mg} / \mathrm{kg}$ PGLE (group C), 20 mg/kg AL $+500 \mathrm{mg} / \mathrm{kg}$ PGLE (group D) and $10 \mathrm{mg} / \mathrm{kg} \mathrm{AL}+750 \mathrm{mg} / \mathrm{kg}$ PGLE (group E). Histological examination of the liver was done using Hematoxylin and Eosin stain.

Results: Various degenerative changes were observed in the liver architecture following aluminum nitrate administration when compared with the control group. Significant regenerative changes similar to control were observed following administration of high dose of Psidium guajava.

Conclusion: The results obtained in this study revealed that aqueous extract of Psidium guajava leaves possess good hepato-protective properties.
\end{abstract}

Keywords: Psidium guajava, Wistar rats, Hepatocytes, Aluminum

\section{Introduction}

Aluminum ( $\mathrm{Al})$ is among the most abundant elements on the earth. Al can be absorbed in humans through the diet as in some food products and additives medication like antacids vaccines and parenteral fluids, cosmetics, inhaled fumes, and particles from occupational exposures [1]. It was believed that $\mathrm{Al}$ was non-toxic but was later known to negatively affect human health [2]. The Agency for Toxic Substances and Disease Registry (ATSDR) stated that Aluminum is mainly distributed in the bone, liver, testis, kidneys, and brain [3].

The liver plays a central role in haematopoiesis, synthesis of coagulation proteins, and regulating many

\footnotetext{
* Correspondence: afoannade@gmail.com

${ }^{1}$ Department of Anatomy, Faculty of Basic Medical Sciences, College of Medicine, Ladoke Akintola University of Technology, Ogbomoso, Nigeria Full list of author information is available at the end of the article
}

important metabolic functions [4]. Liver diseases such as hepatitis, jaundice, cirrhosis and fatty liver are very common and constitute a large public health problem that account for high death rate [5]. Some of these diseases are mainly caused by toxic chemicals, excess consumption of alcohol, infection, among other factors.

Consumption of a variety of local herbs and vegetables by man has been known to contribute significantly to the improvement of human health, in disease prevention, and cure [6]. Psidium guajava is one of the important and valuable plants in folk medicine and is believed to be pharmacologically active [7]. Psidium guajava L., popularly known as guava, is a small tree belonging to the myrtle family (Myrtaceae). Native to tropical areas from southern Mexico to northern South America, many other

\section{Springer Open}

() The Author(s). 2020 Open Access This article is licensed under a Creative Commons Attribution 4.0 International License, which permits use, sharing, adaptation, distribution and reproduction in any medium or format, as long as you give appropriate credit to the original author(s) and the source, provide a link to the Creative Commons licence, and indicate if changes were made. The images or other third party material in this article are included in the article's Creative Commons licence, unless indicated otherwise in a credit line to the material. If material is not included in the article's Creative Commons licence and your intended use is not permitted by statutory regulation or exceeds the permitted use, you will need to obtain permission directly from the copyright holder. To view a copy of this licence, visit http://creativecommons.org/licenses/by/4.0/. 
countries having tropical and subtropical climates have also grown guava trees, thus allowing production around the world [8]. Reports on the phytochemical analyses of guava leaf revealed the presence of more than 20 isolated compounds such as alkaloids, anthocyanins, carotenoids, essential oils, fatty acids, lecitins, phenols, saponins, tannins, triterpenes and vitamin $\mathrm{C}$ [9-11]. Polyphenols are antioxidant that has been shown to attenuate the harmful effects induced by a high-fat diet (HFD) in mouse liver, modulating oxidative stress and preserving the tissue. This hepatoprotective effect would probably be mediated with a change in antioxidant and anti-inflammatory response via transcription factors Nrf2 (Nuclear transcription factor erythroid derived 2- like 2) and NF-kB (Nuclear factor kappa B) respectively [12].

There are reports on hepato-protective effects of $P$. guajava leaf extracts [13-15] but, scanty reports are available on the effect of the aqueous extract of P.guajava leaf in ameliorating environmental toxicant exposed liver in rats.

\section{Materials and methods}

Twenty-five female Wistar rats weighing between 170 and $200 \mathrm{~g}$ were used. They were housed under standard environmental conditions in a standard animal care facility and fed with standard growers' chow and water ad libitum. Five hundred grams of aluminum nitrate was purchased from Denis Chemical Nigeria Company, Ilorin, Kwara State, Nigeria.

\section{Experimental design}

The rats were grouped five groups $(n=5)$, with their weights taken weekly throughout the period of 21 days of the research. Control (group A), $32.5 \mathrm{mg} /$ $\mathrm{kg}$ AL only (group B), $30 \mathrm{mg} / \mathrm{kg} \mathrm{AL}+250 \mathrm{mg} / \mathrm{kg}$ PGLE (group C), $20 \mathrm{mg} / \mathrm{kg} \mathrm{AL}+500 \mathrm{mg} / \mathrm{kg}$ PGLE (group D) and $10 \mathrm{mg} / \mathrm{kg} \quad \mathrm{AL}+750 \mathrm{mg} / \mathrm{kg}$ PGLE (group E).

\section{Preparation of plant extract}

Fresh mature guava leaves used were harvested from the Histology Laboratory, Department of Anatomy, Ladoke Akintola University of Technology, Ogbomoso. The leaves were air-dried for a period of 14 days ( 2 weeks), and then crushed into powder using a mortar and pestle until a fine texture was obtained. The powder was weighed and $542 \mathrm{~g}$ was soaked in $5 \mathrm{l}$ of distilled water and stirred at intervals for 72 hours (3 days). After 3 days, the extract was stirred again and sieved into clean heat-resistant cups with the aid of a sieve with no mesh. The cups containing the extract were then evaporated in a rotary evaporator which was regulated to a temperature of $50{ }^{\circ} \mathrm{C}$.Powdered extracts were obtained and weighed using the sensitive weighing scale.

The rats were sacrificed using mild anesthesia. The liver was harvested, rinsed in normal saline, and then put into specimen bottles containing $10 \%$ formal saline for further tissue processing.

\section{Results}

\section{Discussion}

Histopathological investigation (H\&E) in this study revealed that aluminum affects the architectural and normal cell division of hepatocytes of aluminum exposed rats after 21 days (Fig. 1b). There were severe hemorrhagic cells, congestion of blood in the hepatic vein, widening of sinusoids, and infiltration of inflammatory cells as compared with the control group. This is consistent with earlier finding where aluminum exposure caused proliferation of cells around the portal tract of the liver of rats, which is one of the lesions found in cases of intoxication [16]. Balgoon also noted Hepatic necrosis and degenerated and inflammatory changes in livers of rats receiving aluminum chloride $\left(\mathrm{AlCl}_{3}\right)$ [17]. Degeneration, inflammation, and necrosis caused by hepatocyte damage can result to an increase in the permeability of cell membranes with subsequent increase of indicators of liver damage such asaspartate aminotransferase (AST) and Alanine aminotransferase (ALT) into the blood [18]. Hepatotoxicity of aluminum could probably be due to inhibition of protein synthesis which could potentiate oxidative stress [16]. However, the administration of Psidium guajava leaf extracts ameliorated the congestion of central vein and fibrosis, and causes more regenerative changes in hepatocytes showing the possibility of tissue repair taking place (Fig $1 \mathrm{~d}$ and e). This is consistent with the hepato-protective potential of Psidium guajava in earlier studies against erythromycin, carbon tetrachloride $\left(\mathrm{CCl}_{4}\right)$ liver damage in rats $[14,19,20]$. Histological evidence also suggests that guava leaf powder supplementation ameliorated the fat deposition in liver of high carbohydrate high fat diet fed rats [15]. The observed activity by Psidium guajava could be credited to the chemical compounds such as tannins, flavonoids, pentacyclic triterpenoids, guiajaverin, and quercetin which are present in the extract [21]. Additionally, the hepatoprotective effect of Psidium guajava extract against the damage induced by aluminium might be due to its molecular actions by increasing the antioxidant response via activation of Nuclear transcription factor erythroid derived 2- like 2 (Nrf2) and decreasing the inflammatory response by inactivating Nuclear factor kappa B (NF-kB) which lessen cellular stress and preserve mitochondrial activity [12]. 

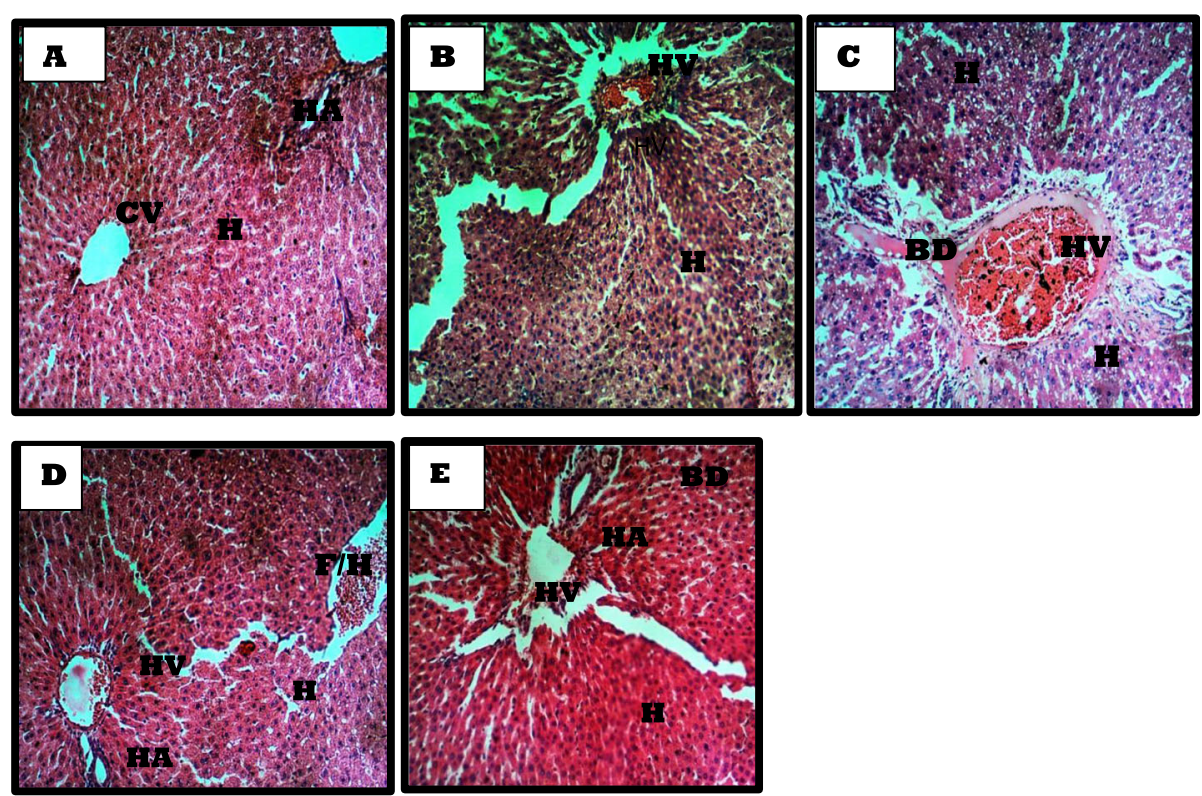

Fig. 1. a-e (400X): Photomicrograph of Liver. CV- Central vein, H- Hepatocyte, HA- hepatic artery, HV- Hepatic vein, BD- bile duct, F/H- Fibrosis/ Hemorroids. a (Group A) - Photomicrograph showed normal cyto-architectural presentation of the hepatocytes and normal portal triad composed of the hepatic vein, hepatic artery, and bile duct. b (Group B) - Photomicrograph showed severe hemorrhagic cells, congestion of blood in the hepatic vein, widening of sinusoids, and infiltration of inflammatory cells as compared with the control group. c (Group C) Photomicrograph showed severe hemorrhagic cells and some fibrosis. $\mathbf{d}$ (Group D) - Photomicrograph showed mild fibrosis, widening of sinusoids, heavy congestion of central vein, some regenerative changes in hepatocytes and mild distortion of the hepatic artery. e (Group E) Photomicrograph showed pronounced widening of sinusoids, mild congestion of central vein, mild fibrosis, and more regenerative changes in hepatocytes

Therefore, it could be concluded that Psidium guajava extract showed some regenerative changes indicating the progressive amelioration of damage caused by aluminum nitrate. However, further study is required on other biomarkers of liver damage induced by aluminum and the mechanistic hepatoprotective effect of $P$. guajava extract.

\section{Acknowledgements}

Not applicable.

\section{Authors' contributions}

AAA conducted the experiment, chiefly supervised by EAA. OIO contributed majorly in writing the manuscript. All authors read and approved the final manuscript.

\section{Funding}

This research was self-funded.

\section{Availability of data and materials}

Not applicable.

\section{Ethics approval and consent to participate}

The animal experiment performed in this study was approved by the Department of Anatomy ethics committee.

\section{Consent for publication}

Not applicable.

\section{Competing interests}

The authors declare they have no competing interest.

\section{Author details}

${ }^{1}$ Department of Anatomy, Faculty of Basic Medical Sciences, College of Medicine, Ladoke Akintola University of Technology, Ogbomoso, Nigeria. ${ }^{2}$ Department of Physiology, College of Health Sciences, Bowen University, Iwo, Nigeria.

Received: 13 February 2020 Accepted: 23 July 2020

Published online: 29 July 2020

\section{References}

1. Inan-Eroglu E, Ayaz A. Is aluminum exposure a risk factor for neurological disorders? J Res Med Sci. 2018;23(1):51.

2. Ozt"Urk B, Ozdemir S. Effects of aluminum chloride on some trace elements and erythrocyte osmotic fragility in rats. Toxicol Ind Health. 2013;31(12):1069-77.

3. Agency for Toxic Substances and Disease Registry (ATSDR). Toxicological profile for aluminum, US Department of Health and Human Services, Public Health Service. 2008, http://www.atsdr.cdc.gov.

4. Juza RM, Pauli EM. Clinical and surgical anatomy of the liver: a review for clinicians. Clin Anat. 2014;27:764-9.

5. Maxwell E, Yusuf $\mathrm{O}$, Ihechiluru E, Blessing E. Effect of Magnifera indica leaf extract on paracetamol-induced hepatic toxicity in rats. Eur J Med Plants. 2014:4(10):1167-77.

6. Chevellier A. The Encylopedia of medical plant. London: Dorling Kindersley Ltd.; 1996. http://www.chclibrary.org/plant.html.

7. Palombo EA. Phytochemicals from traditional medicinal plants used in the treatment of diarrhoea: modes of action and effects on intestinal function. Phytother Res. 2006;20(9):717-24

8. Díaz-de-Cerio E, Verardo V, Gómez-Caravaca AM, Fernández-Gutiérrez A, Segura-Carretero A. Health effects of Psidium guajava L. leaves: an overview of the last decade. Int J Mol Sci. 2017;18:897. https://doi.org/10.3390/ ijms18040897.

9. Begum S, Hassan SI, Siddiqui BS, Shaheen F, Ghayur MN, Gilani AH. Triterpenoidsfrom the leaves of Psidium guajava. Phytochemistry. 2002;63(4): 399-403. 
10. Conde Garcia EA, Nascimento VT, Santiago Santos AB. Inotropic effects of extracts ofPsidium quajava L. leaves on the Guinea pig atricum. Braz J Med Biol Res. 2003;36(5):661-8.

11. Sountornsuk L, Gritsana W, Nilkamhank S, Paochom A. A quantitation of vitamin C. Content in herbal juice using direct titration. J Parm Biomed Anal. 2002;28(5):849-55.

12. Valenzuela R, Illesca P, Echeverría F, Espinosa A, Rincón-Cervera MA, Ortiz M, Hernandez-Rodas MC, Valenzuela A, Videla L. Molecular adaptations underlying the beneficial effects of hydroxytyrosol in the pathogenic alterations induced by a high-fat diet in mouse liver: PPAR-a and Nrf2 activation, and NF-KB down-regulation. Food Funct. 2017:8:1526-37.

13. Chen H, Wu P, Lo D, Pan Y, Wu M. Hepatoprotective effect of guava (Psidium guajava L.) Leaf extracts on ethanol-induced injury on clone 9 rat liver cells. Food Nutr Sci. 2011;2:983-8.

14. Mada SB, Mahammed A, Garba A, Mohammed HA, Garba I. Modulatory. Effect of aqueous stem bark extract of Psidium guajava Linn. Against $\mathrm{CCl}_{4}$ induced liver damage in rats. Am J Biochem Mol Biol. 2013;3(2):215-27.

15. Al Mamun MA, Faruk M, Rahman MM, Nahar K, Kabir F, Alam MA, Subhan N. High carbohydrate high fat diet induced hepatic steatosis and dyslipidemia were ameliorated by Psidiumguajava leaf powder supplementation in rats. Hindawi Evid Based Complement Altern Med. 2019;2019(1897237):12. https://doi.org/10.1155/2019/1897237.

16. Ogueche PN, Ugwu CE, Ezejindu DN, Omeje M, Dike CC, Okonkwo CO, Maduka HC, Obidoa HC. Aluminum intoxication induced biochemical and histopathological alterations in male Wistar Albino rats hepotocytes. J Nat Sci Res. 2014;4(24):6-11.

17. Balgoon MJ. Assessment of the protective effect of Lepidium sativum against aluminum-induced Liver and kidney effects in Albino Rat. Hindawi Bio Med Res Int. 2019;2019(4516730):9. https://doi.org/10.1155/2019/ 4516730.

18. Bai CS, Wang F, Zhao HS, Li YF. Effects of subchronicaluminum exposure on liver function in rats. J Northeast Agric Univ. 2012;19(2):62-5.

19. Sambo N, Garba SH, Timothy H. Effect of the aqueous extract of psidium guajava onErythromycin-induced liver damage in rats. Niger J Physiol Sci. 2009:24(2):171-6.

20. Uboha FE, Iniobong D, Okonb E, Ekong MB. Effect of aqueous extract of Psidium Guajava leaves on liver enzymes, histological integrity and hematological indices in rats. Gastroenterol Res. 2010;3(1):32-8.

21. Ojewole JAO. Hypoglycemic and hypotensive effects of Psidiumguajava Linn. (Myrtaceae) leaf aqueous extract. Methods Find Exp Clin Pharmacol. 2005;27(10):689-95.

\section{Publisher's Note}

Springer Nature remains neutral with regard to jurisdictional claims in published maps and institutional affiliations.

\section{Submit your manuscript to a SpringerOpen ${ }^{\circ}$ journal and benefit from:}

- Convenient online submission

- Rigorous peer review

- Open access: articles freely available online

- High visibility within the field

- Retaining the copyright to your article

Submit your next manuscript at $\boldsymbol{\nabla}$ springeropen.com 